\title{
腰椎椎弓切除後に発生した椎間関節近傍囊腫
}

\section{Juxta Facet Cyst Associated with Lumbar Laminectomy}

\author{
高石吉 將*1 岩橋洋文*3 中 村直人*3 \\ 近藤威 $* 2$ 鵜山淳 $* 3$ 荒井篤*3
}

Yoshiyuki Takaishi, M.D. ${ }^{* 1}$, Hirofumi Iwahashi, M.D. ${ }^{* 3}$, Naoto Nakamura, M.D. ${ }^{* 3}$

Takeshi Kondoh, M.D. ${ }^{* 2}$, Atsushi Uyama, M.D. ${ }^{* 3}$, Atsushi Arai, M.D. ${ }^{* 3}$

\begin{abstract}
Finding Juxta facet cyst is not rare in the era of magnetic resonance imaging (MRI) but little is known regarding cyst formation following lumbar laminectomy. Between 2010 and 2017, we performed lumbar laminectomy on 264 patients. Lumbar laminectomy was performed for either lumbar canal stenosis $(n=221)$ or degenerative spondylolisthesis $(n=43)$. Postoperative MR images were obtained from patients who developed recurrent lumbar pain or leg pain. Juxta facet cysts were diagnosed by MR images. The images demonstrated cyst formation adjacent to the facet joint with low signal intensity on T1-weighted images and high signal intensity on T2-weighted images. Nine patients (3.3\%) were found to have developed juxta facet cysts after lumbar laminectomy. The incidence of cyst formation was higher in the patients with degenerative spondylolisthesis $(n=4,9.3 \%)$ than in patients with lumbar canal stenosis $(n=5,2.3 \%)$. All patients were managed conservatively by medication and/or nerve root block and eight out of nine patients showed resolution of recurrent pain in a few months. The cysts disappeared in four patients as seen in MR images. Juxta facet cyst development following lumbar laminectomy is likely due to facet joint degeneration. The facet joint is covered with ligamentum flavum and injury to the ligamentum during the surgical procedure may accelerate joint degeneration postoperatively.
\end{abstract}

(Received : November 9, 2017 ; accepted : September 14, 2018)

\section{Key words}

lumbar canal stenosis, juxta facet cyst, spondylolisthesis, laminectomy, ligamentum flavum

\section{はじめに}

保存的治療に抵抗する腰部脊柱管狭窄症に対して, 椎 弓切除術は標準的な治療法であり, 手術成績も非常に良 好である。しかし, 術後に症状がいったん改善したが, その後，下肢痛が再燃する例がまれながら存在する，そ のような症例の中に, MRI 上, 椎間関節に連続する囊胞
が認められることがある．椎弓切除術後に発生する椎間 関節近傍囊腫についての報告はほとんどが症例報告1 5) であり，頻度や発生原因についてのまとまった報告は少 ない ${ }^{6 \sim 9)}$. 今回, 術後発生椎間関節近傍囊腫について, 臨床的特徵, 経過について文献的考察を加え, 報告する.

\footnotetext{
*1 慈恵会新須磨病院脊䯣治療センター／Spinal Cord Treatment Center, Jikeikai Shinsuma General Hospital 連絡先：下654-0048 神戸市須磨区衣掛町 3-1-14 慈恵会新須磨病院脊髄治療センター 高石吉將〔Address reprint requests to : Yoshiyuki Takaishi, M.D., Spinal Cord Treatment Center, Jikeikai Shinsuma General Hospital, 3-1-14 Kinugake-cho, Suma-ku, Kobe-shi, Hyogo 654-0048, Japan]

*2 慈恵会新須磨病院ガンマナイフ治療センター／Gamma Knife Treatment Center, Jikeikai Shinsuma General Hospital

*3 慈恵会新須磨病院脳神経外科 /Department of Neurosurgery, Jikeikai Shinsuma General Hospital
} 

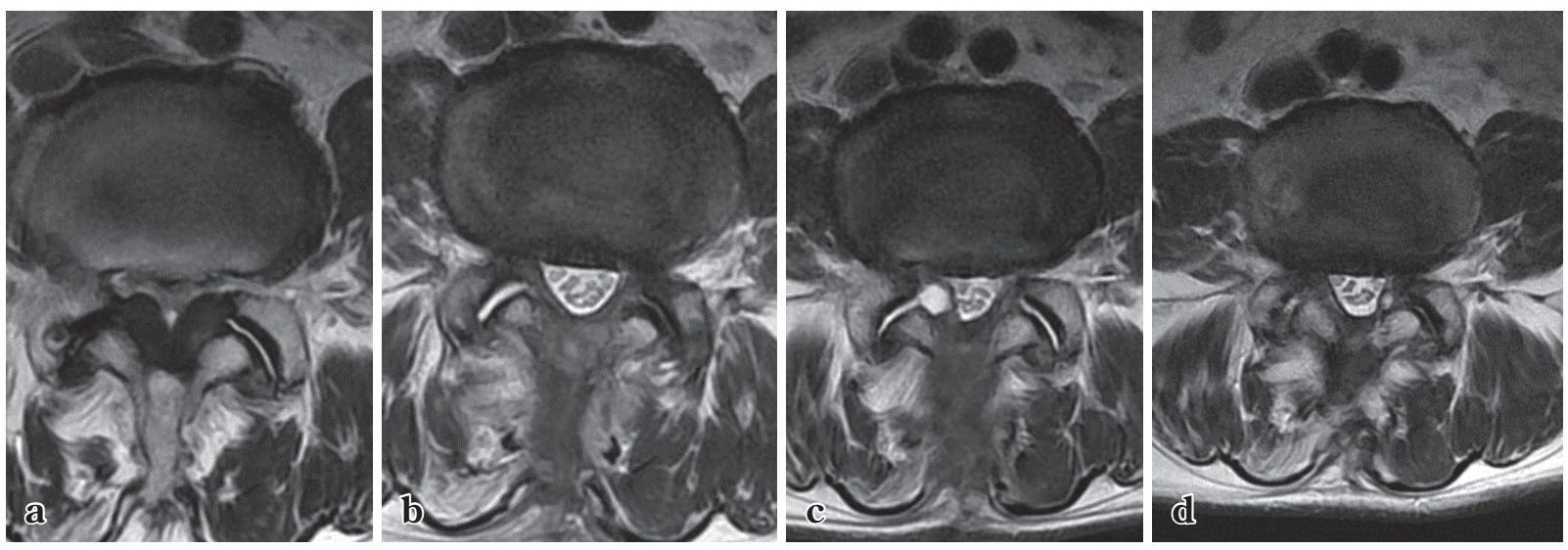

Fig. 1

T2-weighted MR images : Lumbar canal stenosis and facet degeneration were noted preoperatively and is shown on the right side of the image (a). The lumbar spinal canal was sufficiently enlarged postoperatively (b). Three months after surgery, MR imaging for recurrent leg pain demonstrated a newly developed juxta facet cyst as seen on the right side of the image (c). After conservative therapy, juxta facet cyst spontaneously disappeared (d).

\section{対 象}

2010 年 1 月〜 2017 年 9 月の間に, 慈恵会新須磨病院脊 髄治療センターにおいて, 腰椎椎弓切除術を 264 例（腰 部脊柱管狭窄症 221 例, 腰椎変性すべり症 43 例) に対し て施行した。単椎間除圧術を行った症例が 132 例， 2 椎 間除圧術が 105 例, 3 椎間以上が 27 例で, 424 椎間（L1/ $2: 9$ 例, L2/3 $: 41$ 例, L3/4: 126 例, L4/5 : 208 例, L5/ $\mathrm{S} 1 ： 40$ 例）に除圧術を行った。平均 follow up 期間は 31 力月（1９4 力月）で， 93\%の症例で 3 力月以上の外来 followを行うことができた. 退院後は 1 カ月後, 半年後, 1 年後に MRI を行っている.これらの症例のうち, 術後 に腰痛, 下肢痛が再然した症例に対して, 適宜 MRI を施 行し, 症候性椎弓切除後椎間関節近傍囊腫と診断した 9 例について後方視的に検討した，全例，筆頭著者による 執刃である。

間欠性跛行や，高度な下肢痛，下肢麻痺を認めた腰部 脊柱管狭窄症と変性すべり症（Meyerding 分類 Grade I まで）で，動態撮影にて明らかな不安定性（動態撮影で $4 \mathrm{~mm}$ 以上動くもの）を認めないものを手術適応とし, 棘突起縦割式椎弓切除術を行った。棘突起を正中で縦割 し, 椎弓はトランペット型に削除し, 黄色勒帯を除去し て神経根の減圧を行っている。神経根の減圧が十分でな い場合には，椎間関節内側縁の骨削除も施行している.

手術後にいったん術前症状が改善したが，時間経過と ともに下肢痛が出現した症例に対し，MRIを施行し，術 前 MRI と比較し, 椎間関節に連続する T1 強調画像で 低～等信号, T2 強調画像で高信号を呈する囊胞性病変 を新たに認めたものを術後発生椎間関節近傍囊腫と診断
した。

\section{症例提示}

77 歳, 男性.

主 訴: 間欠性跛行。

現病歴 : 約 3 力月前から徐々に腰痛, 両側臀部から下 肢にかけての痛みが出現し, 約 10 分程度の歩行で立ち止 まるようになったため, 当院脊椎外来を受診となった.

神経学的所見: 明らかな麻痺はなく, 約 10 分の間欠性 跛行を認めた。

神経放射線学的所見: LA/5 で黄色勒带の著しい肥厚に よる春柱管狭窄症を認めた。 $\mathrm{L} 4 / 5$ での椎間関節は $\mathrm{T} 2$ 強 調画像において，右側で低信号，左側で高信号を呈して おり，椎間関節の変性も疑われた。

経 過: LA/5 腰部脊柱管狭窄症と診断し, 棘突起縦割 式椎弓切除術を施行した。術後，両足部のしびれ感が残 存したが，間欠性跛行は改善した。しかし，2 カ月後， 右臀部から下肢にかけての痛みが出現し, 外来受診と なった。ただちに MRIを施行したところ，LA/5の右側 の椎間関節に連続する $\mathrm{T} 1$ 強調画像で低信号, $\mathrm{T} 2$ 強調画 像で高信号の脊柱管内囊胞性病変を認めた（Fig. 1)。術 前 MRI では，右側椎間関節が $\mathrm{T} 2$ 強調画像で低信号で あったが，囊腫出現時には T2 強調画像で高信号を呈し ており，関節裂隙も拡大していた。上記の所見より，術 後に発生した椎間関節近傍囊腫と診断した。麻痺は認め なかったため, 保存的に治療を開始し, 約 1 力月で疼痛 は消失，MRIでも囊腫が縮小したことを確認した（Fig. 1). 
Table 1 Summary of patients with postoperative juxta facet cysts

\begin{tabular}{|c|c|c|c|c|c|c|c|}
\hline Case No. & Age and sex & Diagnosis & $\begin{array}{l}\text { Symptoms related } \\
\text { to cysts }\end{array}$ & $\begin{array}{l}\text { Duration (mos) } \\
\text { between surgery } \\
\text { and onset }\end{array}$ & $\begin{array}{c}\text { Level of } \\
\text { laminectomy }\end{array}$ & Level of cysts & Background \\
\hline 1 & $61 \mathrm{~F}$ & LCS & $\begin{array}{l}\text { Low back pain } \\
\text { Rt. leg pain }\end{array}$ & 14 & $\mathrm{~L} 4 / 5$ & $\mathrm{~L} 4 / 5$ & \\
\hline 2 & $76 \mathrm{M}$ & LCS & Low back pain & 2 & $\mathrm{~L} 4 / 5$ & $\mathrm{~L} 4 / 5$ & \\
\hline 3 & $79 \mathrm{M}$ & LCS & Rt. leg pain & 1 & $\mathrm{~L} 4 / 5$ & $\mathrm{~L} 4 / 5$ & \\
\hline 4 & $60 \mathrm{~F}$ & LCS & $\begin{array}{l}\text { Low back pain } \\
\text { Rt. leg pain }\end{array}$ & 1 & $\mathrm{~L} 4 / 5$ & $\mathrm{~L} 4 / 5$ & \\
\hline 5 & $65 \mathrm{M}$ & LCS & $\begin{array}{l}\text { Low back pain } \\
\text { Lt. leg pain }\end{array}$ & 4 & $\mathrm{~L} 4 / 5$ & $\mathrm{~L} 4 / 5$ & $\mathrm{CRF}$ \\
\hline 6 & $52 \mathrm{M}$ & DS & Low back pain & 22 & $\mathrm{~L} 4 / 5, \mathrm{~L} 5 / \mathrm{S} 1$ & $\mathrm{~L} 4 / 5$ & \\
\hline 7 & $66 \mathrm{~F}$ & DS & Lt. leg pain & 2 & $\mathrm{~L} 4 / 5$ & $\mathrm{~L} 4 / 5$ & $\begin{array}{c}\text { Parkinson's } \\
\text { disease }\end{array}$ \\
\hline 8 & $58 \mathrm{M}$ & DS & Low back pain & 2 & $\mathrm{~L} 3 / 4, \mathrm{~L} 4 / 5$ & $\mathrm{~L} 4 / 5$ & \\
\hline 9 & $76 \mathrm{M}$ & DS & $\begin{array}{l}\text { Low back pain } \\
\text { Rt. leg pain }\end{array}$ & 3 & $\mathrm{~L} 3 / 4, \mathrm{~L} 4 / 5$ & $\mathrm{~L} 4 / 5$ & \\
\hline
\end{tabular}

LCS : lumbar canal stenosis, DS : degenerative spondylolisthesis, CRF : chronic renal failure

\section{結 果}

腰部脊柱管狭窄症 221 例, 腰椎変性すべり症に伴う脊 柱管狭窄症 43 例の合計 264 例に対して, 棘突起縦割式椎 弓切除術を施行した.

術後，症候性椎間関節囊腫を認めた症例は 9 例で，男 性 6 例，女性 3 例，平均年齢 $65.9 \pm 9.3$ 歳， $3.3 \%$ の頻度 であった，基礎疾患として，1例にパーキンソン病， 1 例 に慢性腎不全（人工透析）を認めた（Table 1).

手術施行後，症状出現までの期間は 1 22 力月（平均 6.7 カ月) であり, 手術後約 2 力月で症状が出現した症例 が 3 例と最も多かった。症状出現に関して，ほとんどの 症例できっかけとなるものは存在しなかったが，症例 1 に打いては，術後 1 年してから，運動を開始し，それを きっかけにして症状が出現していた。

変性すべり症に生じたものが 4 例 $(9.3 \%)$, 腰部脊柱 管狭乍症に生じたものが 5 例 $(2.3 \%)$ であり, Fisher 直 接検定を行ったところ，変性すべり症に有意に術後椎間 関節囊腫が生じやすいという結果となった（オッズ比 4.43, $\mathrm{p}=0.0416$ ).

囊腫が発生したレベルはすべて L4/5 椎間であり，ほ かの椎間での発生は認めなかった。単椎間除圧を行った 132 例中 6 例に, 多椎間除圧を行った 132 例中 3 例にお いて, 囊腫の出現を認めたが, 統計学的には有意差は認 めなかった（オッズ比 $2.05, \mathrm{p}=0.500 ）$ ．術前の動態撮影 に执いては，明らかな不安定性を呈している症例はな く，術後に動態撮影を行った 2 例（Case 1，7）でも，新 たな不安定性は認めなかった。

$\mathrm{T} 2$ 強調画像において, 囊腫が確認できた画像では, 囊
腫に連続して椎間関節が拡大し，椎間関節内に高信号が 認められる例（facet pooling sign 陽性）が 7/9 例（78\%） に認められた。

疼痛に対しては安静，鎮痛剂，ブロック注射などの保 存的治療を行うことにより，9例中 8 例で，発症から 2 カ月までの間に症状の改善が得られ，MRIを行うことが できた 5 症例で, 囊腫が退縮していることを確認した。 1 例では, 疼痛の軽減，MRI 上での囊腫の縮小を確認し たが，同椎間に椎間板が新たに出現したため，現在も治 療を継続している。

\section{考 察}

椎間関節近傍囊腫は，椎間関節の変性に伴って生じる 囊腫性病変で，春柱管内で神経根を圧迫することで激し い痛みや麻瘏を生じる疾患である。

腰椎の疾患に対して, 容易にMRIが撮影できる時代に なり，椎間関節近傍囊腫はまれな疾患ではなくなってき た，以前は， synovial cystや ganglion cyst などと呼ばれ ていた病態である。この 2 つ鑑別は synovial lining cell の有無によりなされるが，両者の移行型が存在すること もあり，臨床的に両者の鑑別が困難とされ，この囊腫を Kao ら ${ }^{10)}$ は juxta facet cyst として統一し，現在はこの名 称が使用されることが多い，高齢者に多く，発生高位は L4/5が $65 \%$ と最も多いと報告されている ${ }^{11)}$ ，診断は MRI が最も有用で, T1 強調画像で囊腫内部が低信号, T2 強調画像が高信号であり, 被膜は低信号に描出され, ガドリニウムで被膜が造影されるのが特徵的とされてい る。また，梅澤ら ${ }^{11)}$ は横断像で椎間関節の開大と液体貯 
留（facet pooling sign）が 16 例中 14 例（87.5\%）にみら

れ，特徵的な間接所見と報告している.

椎弓切除後の椎間関節近傍囊腫についての報告は少な く，まとまった報告は，検索し得たかぎりでは， 4 編 6 -9) のみであった。

\section{1 発生頻度}

われわれの症例での症候性術後発生椎間関節近傍囊腫 の発生頻度は, 9/264 例（3.3\%）であった。

Walcott $ら^{6)}$ は椎弓切除後の発生頻度を 10/124 例 (8.1\%)，そのうち症候性は 9/124 例 $(7.2 \%)$, Ikuta ら ${ }^{7)}$ は $7 / 81$ 例 $(8.6 \%)$ で, うち症候性は 3 例 $(3.7 \%)$, 西村 8$)$ は 16/112 例 $(14.3 \%)$, うち症候性は 2 例 $(1.8 \%)$, 加藤 $ら^{9)}$ は術後 1 年で $12.2 \%$ の発生率と報告している。症候 性のものに限定すると，1.8～7.2\% と若干のばらつきが あるが, 手術適応の違いや，手術方法にも術者ごとに違 いがあるため, 頻度にばらつきが出現しているものと思 われる。

\section{2 発生原因}

Ikuta $ら^{7)}$ は, 椎間関節近傍囊腫の発生原因として, 術 前・術後の segmental instability が最も影響していると述 べている。, 一方, 西村 ${ }^{8}$ は, 囊腫発生例と非発生例を比 較し, 椎間可動性について検討し, その結果, 椎間可動 性が増加しても囊腫発生が多くなるわけではないと否定 的な見解である。

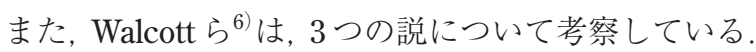
$1 つ$ 目はもともと椎間関節が正常な状態でなく変性が高 度であること，2つ目は骨削除を行った後に医原性の不 安定性が出現したのではないか, 3 つ目は, 椎弓切除術 の際に, 椎間関節を覆っている黄色勒带を削除したこと を挙げている. 代表症例として提示した症例に扔いて も, 術前の右側の椎間関節と囊腫出現後の椎間関節と は, MRI 上の信号が異なっており, 椎間関節へのストレ スにより, 関節の変性が進行し, 囊腫の形成にいたった 可能性があると考えている. 統計学的に検討したとこ ろ, 変性すべり症では腰部脊柱管狭窄症術後に比して発 生頻度が有意に高いという結果であった。変性すべり症 は椎間板の変性だけではなく椎間関節により強い変性が 生じているため, 術後に囊腫が発症する頻度がすべりの ない症例に比べて高いのではないかと推測する.

術後に新たな不安定性が生じているのではないかとい う点については, 術後, 動態撮影を行った症例において は, 動態撮影上不安定性が確認できなかった。しかし, 術後, 動態撮影に打いて不安定性が出現し, それに伴っ て囊腫が形成されたという報告5)もあり，動態撮影では とらえきれない動きが，発症に関与している可能性もあ
ると思われる。

椎弓切除術において, 痛みを取り除くためには, common dural sacのみならず, root sleeveの減圧を十分に行 う必要がある。特にすべり症を有する例や, lateral recess stenosis を合併している症例については, 黄色勒 帯に加えて椎間関節内側縁の骨を一部削除する必要があ ると考える.これらの操作は, 椎間関節近傍囊腫の発生 には少なからず影響している可能性はあると思われる。

\section{3 治療法}

過去の報告に抢いて, 術後に発生したものでない原発 性椎間関節近傍囊腫は，ほとんどの例において外科的な 治療を行っている.しかし, 術後発生のものについては, 保存的治療を行っているもの, 椎間関節内久テロイド注 射, 手術など, 種々の方法が報告されている. Walcott $ら^{6)}$ は, 10 例の囊腫に対して, 5 例に再手術，5例に硬膜 外ステロイド注射による治療を行っている. 当院では全 例, 保存的に治療を行い, 9 例中 8 例で症状は改善し, 囊腫の縮小を 5 例で確認した。加藤ら ${ }^{9)}$ の報告でも, 術 後 3 力月に発生した囊腫の約 $40 \%$ が自然消失し, Ikuta ら $も 7$ 例中 5 例 $(71 \%)$ で, 3〜36 カ月の間に, 症状の 改善を確認している.

原発性椎間関節近傍囊腫に対する手術も行っている が, その際被膜は非常に厚く, 硬膜との癒着も強い症例 が多い。このような厚い被膜が形成されると，自然治癒 は期待できない。術後発生椎間関節近傍囊腫においては 比較的急性発症であり，厚い被膜が形成されていないた め, 自然治癒が起こり得るのではないかと考える.

原発性椎間関節近傍囊腫では, 自然退縮はなかなか期 待できるものではないが, 術後発生では保存的治療でも 症状の改善が得られることが多いため, まずはしばらく の間保存的に加療を行うのが望ましいと考える.

\section{結 語}

椎弓切除後に発生した椎間関節近傍囊腫の 9 例につい て報告した。

当院における発生頻度は, 変性すべり症で $4 / 43$ 例 $(9.3 \%)$, 腰部脊柱管狭窄症で $5 / 221$ 例 $(2.3 \%)$ と統計学 的に有意差を認めた。

もともとの椎間関節の変性の程度や, 神経根減圧のた めの椎間関節内側縁の骨削除が, 術後の囊腫発生に影響 している可能性があると考えられた。

9 例中 8 例が保存的治療に反応し, 疼痛の軽減を確認 した. 残り 1 例は疼痛の軽減と MRI 上の囊腫の縮小を確 認したが, 同部位に新たに椎間板へルニアを生じたため 
現在も治療継続している。術後発生椎間関節近傍囊腫で は自然退縮する可能性を考え，まず保存的治療を行い，

経過をみる必要があると思われる。

\section{利益相反について}

本論文に関して，開示すべきCOI はありません。

\section{文 献}

1) Cho SI, Lee JH, Chough CK : Postlaminectomy bilateral lumbar intraspinal synovial cysts. Korean J Spine $13: 157-159,2016$

2) 村田盛郎, 桶田大輔, 神本 篤: 椎弓切除後に発生した腰部 脊柱管内滑膜囊腫の 1 例。東海脊椎外 $\mathbf{1 6}: 31-36,2002$

3）鍋田正晴 : 腰部脊柱管狭窄症に対する除圧術後椎間関節囊腫 の発生を繰り返した 1 例。中部整災誌 53:1195-1196, 2010

4）柿丸裕之, 伊藤修司, 松本亮紀, 他 : 腰部脊柱管狭窄症術後
に発生した脊柱管内囊腫。中部整災誌 $58 ： 105-106,2015$

5) Kim HS, Kim SW : Hemorrhagic lumbar synovial cyst after microscopic discectomy. Korean J Spine 14:93-95, 2017

6) Walcott BP, Coumans JV : Postlaminectomy synovial cyst formation : a possible consequence of ligamentum flavum excision. J Clini Neurosci 19 : 252-254, 2011

7) Ikuta K, Tono O, Oga M : Prevalence and clinical features of intraspinal facet cysts after decompression surgery for lumbar spinal stenosis. J Neurosurg Spine 10 : 617-622, 2009

8）西村行政：腰部脊柱管狭窄症に対する後方除圧術後の椎間関 節囊腫。整形外科 $63: 301-304,2012$

9）加藤相勲, 小西定彦, 松村 昭：顕微鏡視下片側進入両側除 圧術後に生じた腰椎椎間関節囊腫の検討。中部整災誌 56 : 57-58, 2013

10) Kao CC, Winkler SS, Turner JH : Synovial cyst of spinal facet. Case report.J Neurosurg $41: 372-376,1974$

11）梅澤夏樹, 徳橋泰明：腰椎椎間関節囊腫。日大醫學雑誌 68 : 221-224, 2009 